\title{
Píseň zůstane ve mně navždy
}

\author{
František Všetička \\ (Olomouc, Česká republika)
}

Po druhé světové válce nastoupila v polské literatuře výrazná generace, jejíž součástí byl i Longin Jan Okoń (ročník 1927). Debutoval roku 1949 básnickou sbírkou Slzy srdce (Łzy serca). Za jistých okolností přišel předčasně, poněvadž na jeho druhotinu museli čtenáři čekat dalších deset let (stal se jí svazek Večerní melodie - Nuty wieczorne). Od svých generačních druhů se začal Okoń odlišovat mimo jiné tím, že postupně rozšiřoval svůj druhový a žánrový rejstř́k. K poezii přistoupila próza a literární historie. Zájmové nůžky se značně rozevřely.

Jedno z dominantních témat Okońovy poezie naznačují názvy jeho sbírek: Večerní melodie, Barvy dnů (Barwy dni), Stíny času (Cienie czasu), Chytání úsvitu (Łowienie świtu) a Hloubil jsem noc (Drążyłem noc). Je to téma času, které zdaleka netkví pouze v titulech jeho sbírek, ale přímo v jeho verších. Čas není podle Okoně lidské bytosti nijak nakloněn. V básni Stíny (Cienie, ze sbírky Oblaka země - Mroki ziemi) čas klade věčné stíny pomíjivosti - czas kładzie wieczne cienie przemijania. Tato myšlenka je rozvedena v básni Ticho a čas (Cisza i czas), jež jej charakterizuje těmito slovy:

Čas je věčný
mlčicí potměšilý
podvádí jak váha
špatně vyvážená
a nepozorovaně
zdírá naše tkáně...

\author{
Czes jest wieczny \\ milczacy podstępny \\ oszukuje jak waga \\ źle starowana \\ i niepostrzeżenie \\ struga nasze tkanki...
}

Okoń není ovšem pesimista, ve sbírce příznačně nazvané Kámen a naděje (Kamień i nadzieja) má báseň Zítřek (Jutro), kterou uzavírá trojverším: 
deštěm vykoupaný úsvit

odhaluje

nebetyčný zítřek deszczem skąpany świt

odstania

wysokopienne jutro

Okońův čas má tedy dvojí tvářr, a do značné míry, i když v jiné rovině, to platí i o jeho tvorbě, jež vedle básnické podoby má též podobu prozaickou. Okoń se dokonce stal daleko známější jako prozaik, a to především svou trilogií o Indiánech. Tvoří ji romány Tecumseh, Generál rudochů (Czerwonoskóry generál) a Stopami Tecumseha (Śladami Tecumseha), které vyšly ve čtyřech vydáních. K těmto prózám třeba připojit také Okońovu práci v organizacích na obranu indiánského společenství. Stanisław Koszewski shrnul všechnu tuto jeho činnost do lapidárního tetrastichu:

Místo vyprávění o dvorech, pánech psal dila o ubohých Indiánech.

Mnozí se pyšnili jejich pogromy,

Longin je však bral do ochrany.
Miast opowiadać o dworach, panach pisat tomy o biednych Indianach.

Wielu szczycito się ich pogromem, Longin świadomie brat ich w obronę.

Longin Jan Okoń je konečně také literární historik. Po řadě drobnějších portrétů o autorech chełmské oblasti shrnul své poznatky do panoramatického přehledu s názvem Historie literatury chełmského kraje (Historia literatury ziemi chełmskiej). V této publikaci zachytil vývoj krajového písemnictví od středověku po současnost. Okońův stostránkový počin je obsáhlou rozpravou, kterou v druhé půli doplňují a zvýrazňují další autoři řadou dílčích prŕíspěvků. I v tomto směru je autor Oblaků země iniciátorem.

Ve zmíněné sbírce se nachází téměř programová báseň s názvem Lyrika (Liryka), v níž Okoń na sebe mnohé prozrazuje. Závazný v ní zůstává její vyznávací explicit: píseň zůstane ve mně navždy - pieśń zostanie ze mnq na zawsze.

\section{About the author}

\section{František Všetička}

Olomouc, Česká republika

fvseticka@seznam.cz

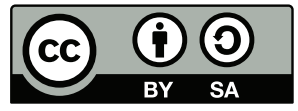

Toto dílo Ize užít v souladu s licenčními podmínkami Creative Commons BY-SA 4.0 International (<https:// creativecommons.org/licenses/by-sa/4.0/legalcode>). Uvedené se nevztahuje na díla či prvky (např. obrazovou či fotografickou dokumentaci), které jsou v díle užity na základě smluvní licence nebo výjimky či omezení príslušných práv. 